\title{
A self-supported 40W direct methanol fuel cell system
}

\author{
A MANOKARAN $^{\mathrm{a}}, \mathrm{R}_{\text {VIJAYAKUMAR }}^{\mathrm{a}}, \mathrm{T}^{\mathrm{N}}$ THOMMAN $^{\mathrm{a}}, \mathrm{P}$ SRIDHAR $^{\mathrm{a}}$, S PITCHUMANI $^{\mathrm{a}}$ \\ and A K SHUKLA ${ }^{\mathrm{b}, *}$ \\ ${ }^{a}$ Central Electrochemical Research Institute (CECRI), Madras Unit, CSIR Complex, Chennai 600 113, India \\ ${ }^{\mathrm{b}}$ Solid State and Structural Chemistry Unit, Indian Institute of Science, Bangalore 560 012, India \\ e-mail: akshukla2006@gmail.com
}

MS received 2 September 2010; accepted 29 December 2010

\begin{abstract}
A self-supported 40W Direct Methanol Fuel Cell (DMFC) system has been developed and performance tested. The auxiliaries in the DMFC system comprise a methanol sensor, a liquid-level indicator, and fuel and air pumps that consume a total power of about $5 \mathrm{~W}$. The system has a 15-cell DMFC stack with active electrode-area of $45 \mathrm{~cm}^{2}$. The self-supported DMFC system addresses issues related to water recovery from the cathode exhaust, and maintains a constant methanol-feed concentration with thermal management in the system. Pure methanol and water from cathode exhaust are pumped to the methanol-mixing tank where the liquid level is monitored and controlled with the help of a liquid-level indicator. During the operation, methanol concentration in the feed solution at the stack outlet is monitored using a methanol sensor, and pure methanol is added to restore the desired methanol concentration in the feed tank by adding the product water from the cathode exhaust. The feed-rate requirements of fuel and oxidant are designed for the stack capacity of $40 \mathrm{~W}$. The self-supported DMFC system is ideally suited for various defense and civil applications and, in particular, for charging the storage batteries.
\end{abstract}

Keywords. DMFC; methanol balance; closed loop.

\section{Introduction}

Direct methanol fuel cells (DMFCs) are attractive for portable-power applications due to their simplicity and use of methanol as a high-energy-density-liquid fuel. ${ }^{1-3}$ Nafion, a perfluorosulfonic acid polymer, is the most commonly used proton-exchange membrane in DMFCs owing to its excellent chemical stability and high proton-conductivity. However, Nafion membranes are prone to methanol permeation, commonly referred to as methanol crossover, as methanol can easily transport together with solvated protons through the water-filledion-cluster channels available within the Nafion structure. ${ }^{4}$ It is noteworthy that methanol crossover from anode to cathode is one of the major problems limiting the commercialization of DMFCs, because it not only wastes the fuel but also causes performance losses at the cathode due to the mixed-potential effect and catalyst poisoning. ${ }^{5-8}$ Accordingly, it is necessary to consider the operational characteristics of all the constituents in the system to optimize the performance of a DMFC system. ${ }^{9}$ In brief, it is not sufficient to optimize just the current-potential curves for the fuel

*For correspondence cell without accounting other system-related problems. Water crossover through the membrane and the ensuing vaporization at the cathode side impair the thermal balance and the parameters which influence these effects, namely temperature, air flow and methanol-permeation rate. In the present study, based on the single-cell performance, the power output of the cell is fixed, and the methanol requirement and water balance are evaluated for the uninterrupted operation of the system based on the power output. A 15-cell $40 \mathrm{~W}$ DMFC system is developed and bench marked using the base requirement for a single cell.

\section{Experimental}

Commercially available BASF MEAs with perfluorocarbon membrane of 127 micron in thickness and an active electrode area of $45 \mathrm{~cm}^{2}$ were used to assemble the cell/stack. Both the flow fields were multiserpentine patterns with the channel depth and width of $1 \mathrm{~mm}$ each. The operating temperature of the cells was kept at $60^{\circ} \mathrm{C}$, and the flow rates for methanol and air were kept at $5 \mathrm{ml} / \mathrm{min}$ and $0.5 \mathrm{slpm}$, respectively. The single cells were tested, using Bitrode (US) Instrument, with varying methanol concentrations, namely $1 \mathrm{M}$ and 
Table 1. Specifications for balance-of-plant.

\begin{tabular}{|c|c|c|c|}
\hline Component & $\begin{array}{l}\text { Model No./Power } \\
\text { consumption(W) }\end{array}$ & $\begin{array}{l}\text { Input } \\
\text { voltage }\end{array}$ & $\begin{array}{l}\text { Output } \\
\text { parameters }\end{array}$ \\
\hline Diluted methanol pump & NF $1.11 / 2.2$ & 6 & $52 \mathrm{mlpm}$ \\
\hline Air pump & T4-2HE-06-1SNA/1.5 & 6 & $7.5 \mathrm{slpm}$ \\
\hline Concentration sensor & FC6/0.2 & 5 & $0-2 \mathrm{~V}$ \\
\hline Level sensor & S18UIA/0.4608 & $10-32$ & $4-20 \mathrm{~mA}$ \\
\hline Concentrated methanol pump & NF $5 / 0.65$ & 12 & $60 \mathrm{mlpm}$ \\
\hline Cooling fan & San Ace 80/2 & 12 & 1200 slpm \\
\hline
\end{tabular}

$4 \mathrm{M}$, at constant flow rate. The DMFC stack comprising 15 cells was assembled with BASF MEAs with an active electrode area of $45 \mathrm{~cm}^{2}$. The bi-polar graphite plates (Entegris Inc., US) were $5 \mathrm{~mm}$ thick with $1 \mathrm{~mm}$ deep flow channels. The stack was internally manifolded. The DMFC system comprised DMFC stack, air pump, methanol pump, concentration and level sensors, and methanol tanks containing $1 \mathrm{M}$ methanol and 24.7 M methanol, battery pack for initial start-up of the pumps and digital voltmeter for display. A schematic diagram of the DMFC system is given in figure 1 and the specifications for the Balance-of-Plant (BoP) are given in table 1.

\section{Results and discussion}

\subsection{Methanol-balance studies}

For DMFC system studies, the methanol balance equation is given by: crossover volume of methanol $=$ volume at the inlet - (volume at the outlet + volume reacted). Volumes of methanol at the inlet and outlet are obtained using a density meter (Mettler Toledo, US). Inlet and outlet methanol solution densities are measured with density meter. Volume of methanol reacted is equivalent to faradaic oxidation of methanol. The methanol balance study is performed on single cells. Aqueous methanol solution and air at a flow rate of $2 \mathrm{ml} / \mathrm{min}$ and $150 \mathrm{ml} / \mathrm{min}$ are supplied to the anode and cathode, respectively. The temperature of the cell is maintained at $60^{\circ} \mathrm{C}$. The effects of current density, concentration of methanol and depth of flow field on the cross-over current are studied. The effect of load current-densities on the cross-over current for varying methanol concentrations is given in figure 2. As seen from the data, the crossover of methanol decreases with increasing load current-density. At higher currentdensities, the utilization of methanol is higher and accordingly the methanol crossover decreases with increase in current density. At the same time, increasing the concentration of methanol at the inlet significantly increases the crossover current-density due to an increase in the concentration difference between

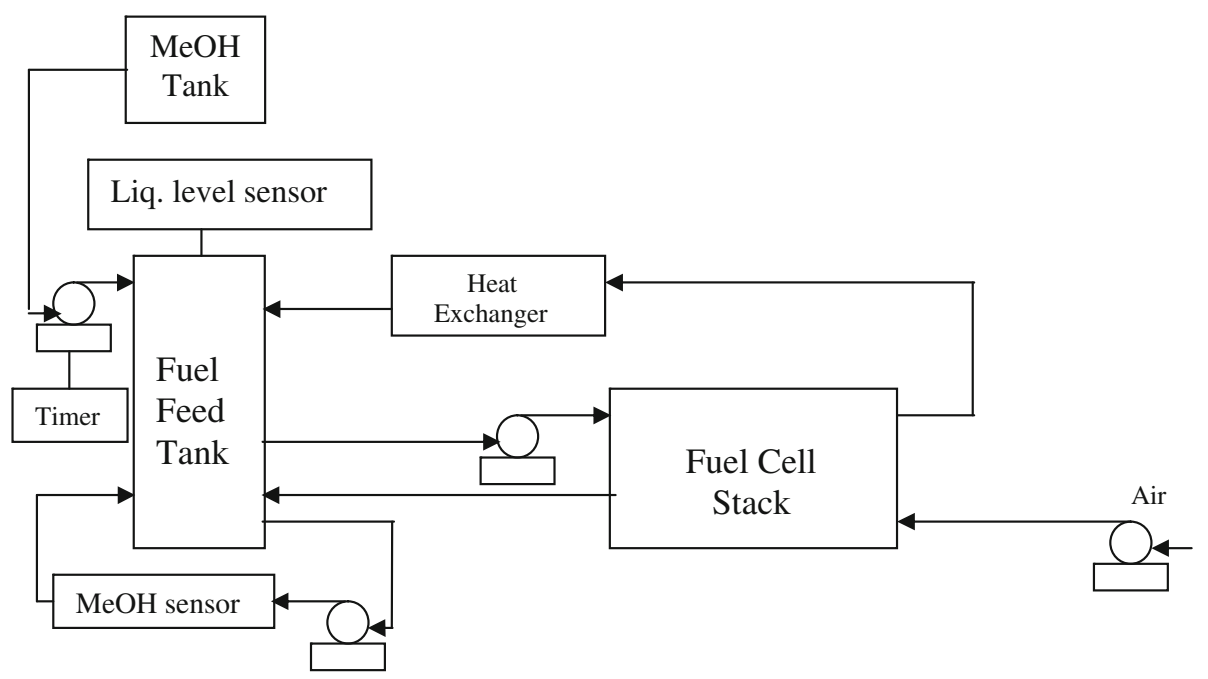

Figure 1. Schematic diagram of the DMFC system. 


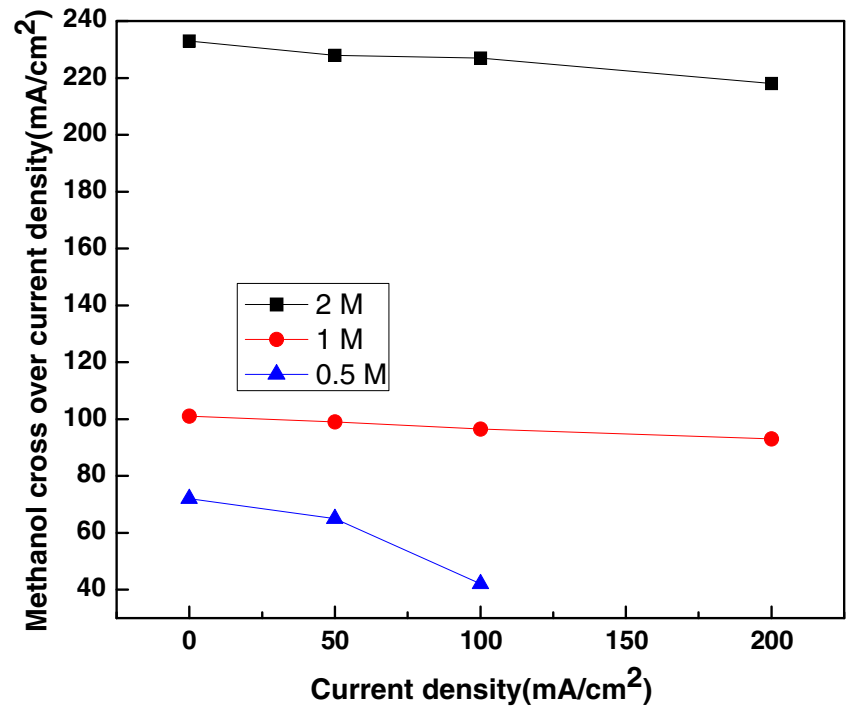

Figure 2. Dependence of parasitic crossover currentdensity on the operating current-density of the DMFC with $0.5 \mathrm{M}, 1 \mathrm{M}$ and $2 \mathrm{M}$ aqueous methanol.

catalyst layer and membrane. The results obtained are in agreement with the literature. ${ }^{10}$

The effect of channel depth in the cathode flow-field on methanol crossover is studied and the results are presented in figure 3. As the cathode flow-field-depth increases, the crossover of methanol decreases due to decrease in pressure drop across the flow field. Based on the above studies, the depth of the cathode flow-field channels is fixed as $1 \mathrm{~mm}$. Polarization studies are conducted to determine the methanol concentration and the

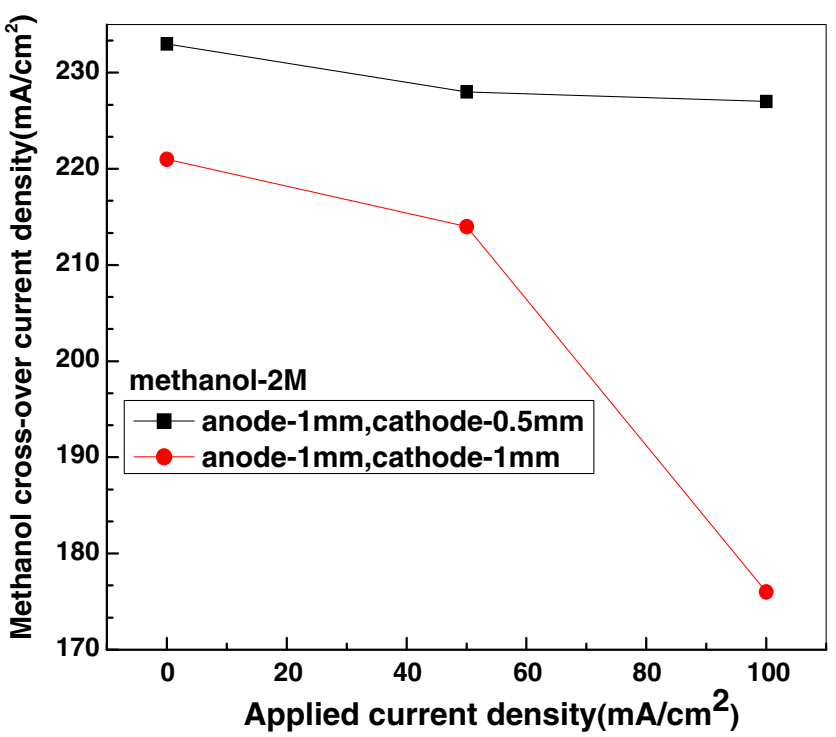

Figure 3. Effect of different cathode flow-field depths on methanol cross-over.

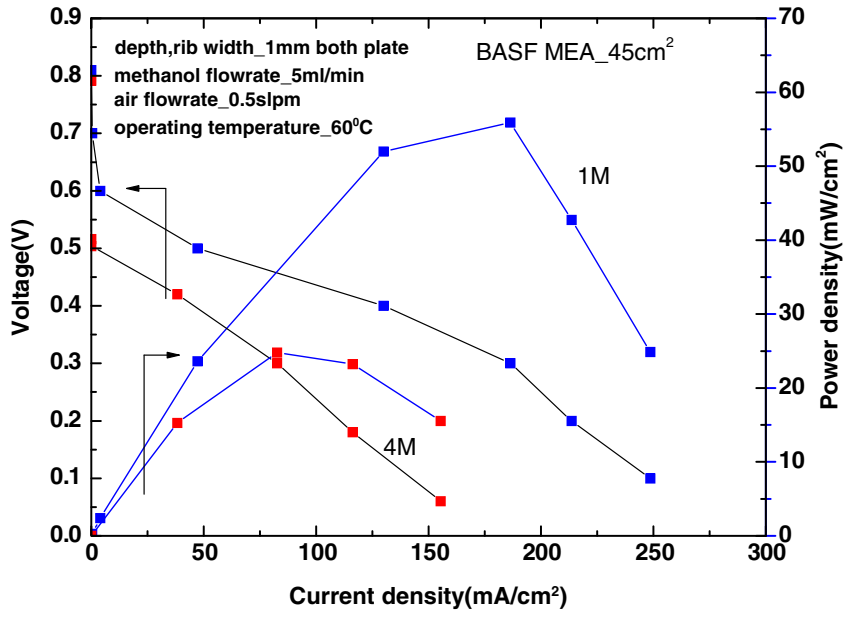

Figure 4. Performance curves for a DMFC single cell with active area of $45 \mathrm{~cm}^{2}$ for varying methanol concentrations.

results are given in figure 4 . The data reflect that with $1 \mathrm{M}$ aqueous methanol solution, the power densities at all current densities are superior in comparison with $4 \mathrm{M}$ aqueous methanol. Accordingly, the concentration of methanol for further studies is kept at $1 \mathrm{M}$.

\subsection{Single-cell polarization studies}

Single-cell polarization studies are conducted at a constant load current-density to monitor the power output with time to study the methanol and water balance for up-scaling. The results are presented in figure 5 . It is seen from the data in figure 5 that there is a sudden drop in voltage after $30 \mathrm{~min}$ of continuous operation. The drop in performance is found to be due to the decrease in methanol-feed concentration to the cell.

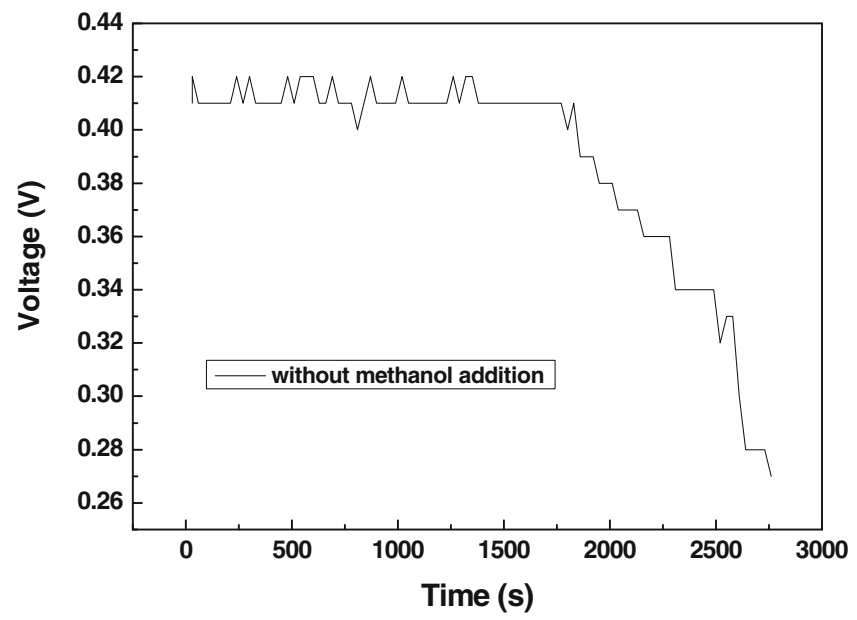

Figure 5. Voltage response at a load current-density of $133 \mathrm{~mA} / \mathrm{cm}^{2}$. 


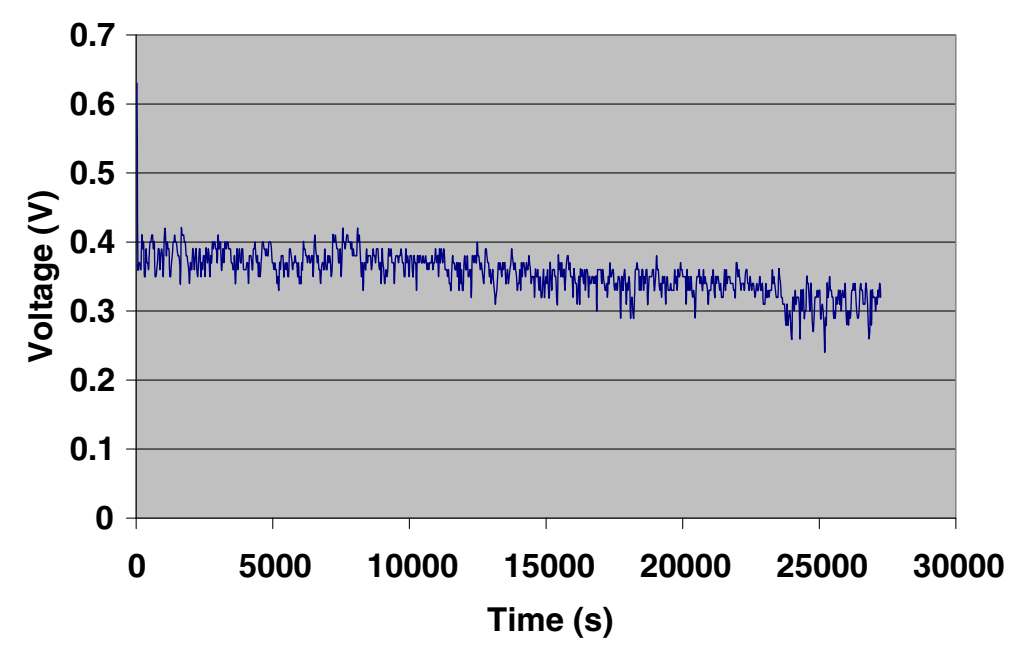

Figure 6. Voltage response at constant load-current of $6 \mathrm{~A}$.

In order to determine the amount of methanol to be added to the feed tank after $30 \mathrm{~min}$ of operation and to sustain constant voltage at a load-current density of $133 \mathrm{~mA} / \mathrm{cm}^{2}$, the methanol balance is determined as: initial methanol concentration $=$ reacted methanol (from current) + crossover methanol (experimental data) + methanol evaporated (experimental data) + methanol remaining in the tank.

Based on Faraday's law, methanol consumption is computed for a constant load-current of $6 \mathrm{~A}$. Crossover methanol is determined based on the data presented in figure 2. Methanol loss due to evaporation is determined separately based on density measurements by keeping $1 \mathrm{M}$ aqueous methanol at $60^{\circ} \mathrm{C}$ for 30 min under identical experimental conditions. The difference between the initial and final methanol concentrations in the feed

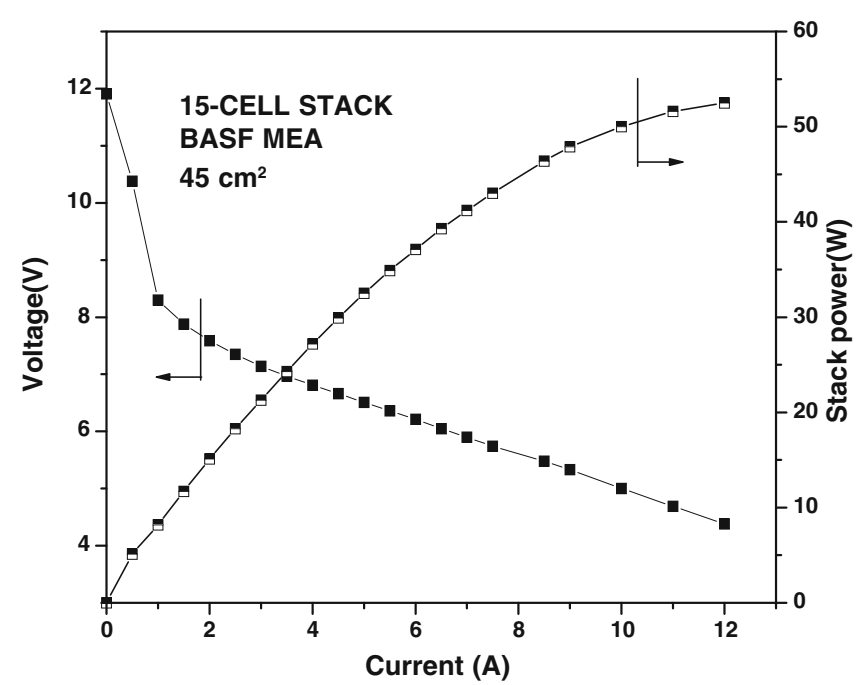

Figure 7. Performance curves for the 15-cell DMFC stack. tank with $200 \mathrm{ml}$ solution after $30 \mathrm{~min}$ of operation is found equivalent to $2 \mathrm{ml}$ of $24.7 \mathrm{M}$ methanol. Singlecell study is performed with a provision to add $2 \mathrm{ml}$ of 24.7 M methanol for every $30 \mathrm{~min}$ with a timer attached to the methanol feed-tank. With the above arrangement, the cell voltage is found to remain nearly constant for about $8 \mathrm{~h}$ operation as shown in figure 6 . The solution level in the feed tank remains fairly constant as indicated by the level sensor. It is found that the water consumed at the anode and water produced at the cathode, and water loss due to evaporation balance well.

\subsection{Stack-performance studies}

Based on the single-cell-polarization studies and methanol balance, a DMFC system comprising a 15cell stack is evaluated. The stack performance at $60^{\circ} \mathrm{C}$

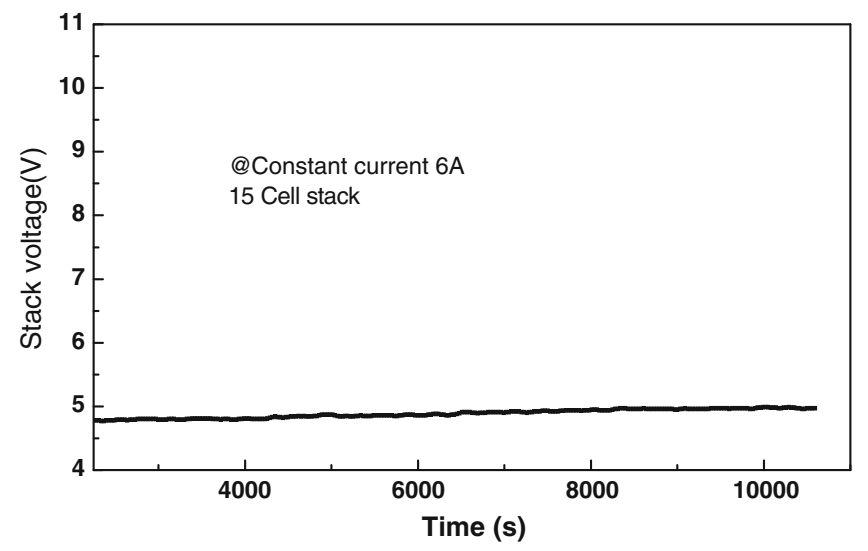

Figure 8. Voltage response for the 15-cell DMFC stack at a constant load-current of $6 \mathrm{~A}$. 
is given in figure 7. It is interesting to note that the voltage of a single cell and the average cell voltage of the 15 -cell stack at a load current-density of $133 \mathrm{~mA} / \mathrm{cm}^{2}$ are nearly similar. Based on the single-cell study, the requirement for methanol addition is found to be $30 \mathrm{ml}$ of $24.7 \mathrm{M}$ aqueous methanol made to $200 \mathrm{ml}$ in the feed tank for every $30 \mathrm{~min}$. It is required to add $2 \mathrm{ml}$ of $24.7 \mathrm{M}$ aqueous methanol every $2 \mathrm{~min}$ to the feed tank of the DMFC system to keep the stack voltage constant for nearly $3 \mathrm{~h}$ at a load current-density of $133 \mathrm{~mA} / \mathrm{cm}^{2}$ as shown in figure 8 .

\section{Conclusions}

A self-sustained $40 \mathrm{~W}$ DMFC system operating at ambient temperature has been assembled and performance tested. It is shown that by careful analysis of methanol and water balance, it is possible to operate the DMFC system without any interruption for a prolonged period.

\section{Acknowledgements}

Financial support from Council of Scientific and Industrial Research (CSIR), New Delhi through a
Supra-Institutional Project under EFYP is gratefully acknowledged.

\section{References}

1. Antolini E, Salgado J R C and Gonzalez E R 2006 Appl. Catal., B Environ. 63137

2. Deluca N W and Elabd Y A 2006 J. Polym. Sci.: Part B: Polym. symp. $\mathbf{4 4} 2201$

3. Neburchilov V, Martin J, Wang H and Zhang J $2007 \mathrm{~J}$. Power sources 169221

4. Heinzel A and Barragán V M 1999 J. Power Sources 84 70

5. Ravikumar M K and Shukla A K 1996 J. Electrochem. Soc. 1432601

6. Jiang R and Chu D 2004 J. Electrochem. Soc. 151 A69A76

7. Scott K, Taama WM, Argyropoulos $\mathrm{P}$ and Sundmacher K 1999 J. Power Sources 83204

8. Gurau B and Smotkin ES 2002 J. Power Sources 112 339

9. Narayanan S R and Valdez T I 2003 Handbook of fuel cells - Fundamentals, technology and applications (eds) Wolf Vielstich, Arnold Lamm and Hubert Gasteiger (Chichester: John Wiley \& Sons) Chapter 81 pp. 1133

10. Dohle H, Schmitz H, Bewer T, Mergel J and Stolten D 2002 J. Power Sources 106313 